\title{
The Fables of Pity: Rousseau, Mandeville and the Animal-Fable
}

\author{
Sean Gaston
}

\begin{abstract}
Prompted by Derrida's work on the animal-fable in eighteenth-century debates about political power, this article examines the role played by the fiction of the animal in thinking of pity as either a natural virtue (in Rousseau's Second Discourse) or as a natural passion (in Mandeville's The Fable of the Bees). The war of fables between Rousseau and Mandeville - and their hostile reception by Samuel Johnson and Adam Smith - reinforce that the animal-fable illustrates not so much the proper of man as the possibilities and limitations of a moral philosophy that is unable to address the political realities of the state.
\end{abstract}

$*$

Goldsmith said, that he thought he could write a good fable, mentioned the simplicity which that kind of composition requires, and observed, that in most fables the animals introduced seldom talk in character. (Boswell 1998, 524)

As Derrida pointed out in La Bête et le souverain I (2001-2), the animal plays a significant role as a trope in discussions about political power and moral philosophy in the seventeenth and eighteenth centuries. To cite one common example, which Derrida addresses, like the wolf the sovereign is deemed to be above or outside of the law (Derrida 2009, 16-17; 33-5; 57; 96). ${ }^{1}$ Rousseau's account of natural pity in

Derrida Today 5.1 (2012): 21-38

DOI: $10.3366 /$ drt.2012.0026

(C) Edinburgh University Press

www.eupjournals.com/drt 
the Discourse on the Origin and Foundations of Inequality Among Men (1755) can be read as a fable that relies on a series of illustrative fictions of the animal. At the same time, there is a war of fables in Rousseau's attacks on Mandeville's The Fable of Bees; Or, Private Vices, Publick Virtues (1714, 1723, 1729), a work whose very title had placed the fabula of the animal at the heart of eighteenth-century moral philosophy (Derrida 2009, 98). As Derrida suggested, in the name of a moral philosophy for civil society - an impossible task - the fictions of the animal-fable must relentlessly attempt to illustrate the elusive 'proper of man' (Derrida 2009, 82-3; 138-9).

Having used Derrida's work in a previous article on the impossibility of sympathy in the eighteenth century, I would like to take Derrida's late seminar as a prompt to re-think the role played by the fable of the animal in the Second Discourse and in The Fable of the Bees (Gaston 2010). Both Mandeville and Rousseau use fables or fictions of animals to illustrate the human attributes of pity as, respectively, a natural passion and a natural virtue. Despite their clear differences-Mandeville links the animal-like natural passions to the lack of rational virtues and the limitations of civil society, while Rousseau suggests that the animallike natural virtues of natural man can be treated as the possibility of social virtues in civil society-both reinforce the connection between a seemingly given natural moral behaviour and a necessary fiction. As Derrida observes in La Bête et le souverain:

If I place so much emphasis on the fable and the fabulous [...] The point is, as the fables themselves show, that the essence of political force and power, where that power makes the law, where it gives itself right, where it appropriates legitimate violence and legitimates its own arbitrary violence-this unchaining and enchaining of power passes via the fable, i.e. speech that is both fictional and performative. (Derrida 2009, 217) ${ }^{2}$

In the eighteenth century, the problem of human social morality appears to require a series of animal-like fables, where it is not the animal (as the other of the human) but the fiction of the animal that announce both the possibilities and the limitations of these moral philosophies in relation to the political realities of the state.

\section{A Pre-rational, Pre-moral and Pre-social Fable}

After having touched on the dilemma of whether language precedes the formation of society or is produced by it in the Second Discourse, Rousseau devotes a few pages to the virtue of natural pity (Rousseau 
1997, 151-4). 'In instinct alone', he observes, natural man 'had all he needed to live in the state of Nature' (Rousseau 1997, 150). Itinerant and independent, men had no 'moral relations of any sort between them' but they were nonetheless imbued with the natural virtue of pity (Ibid. 150). This pre-moral virtue is an instinctual virtue. Rousseau attempts to account for the relations between those in a state of nature who had no natural need of other people but still expressed a natural pity for others, even though they had yet to experience the moral complexity of the 'universal dependence' that informs civil society (Rousseau 1997, 151). As he observes after his discussion of language:

Whatever may be the case regarding these origins, it is at least clear, from how little care Nature has taken to bring Men together through mutual needs and to facilitate their use of speech, how little it prepared their Sociability, and how little of its own it has contributed to all that men have done to establish its bonds. Indeed, it is impossible to imagine why, in that primitive state, a man would need another man anymore than a monkey or a Wolf would need his kind, or, assuming this need, to imagine what motives could induce the other to attend to it, or even if it did, how they might agree on terms. (Rousseau 1997, 149)

In his search for a 'universal' natural motive that would precede 'moral relations' and explain why one person would recognise and concern themselves with the needs of others of their species, Rousseau equates primitive man with the wolf or the monkey. He also insists that these pre-moral relations -in which man, the wolf and the monkey are analogous - are not inherently or absolutely self-centred (Derrida 2008a, 342). There is no reason to accept Hobbes's apparent view, Rousseau insists, that 'by the virtue of the right which he reasonably claims to the things he needs', the natural man 'insanely imagines himself to be the sole owner of the entire Universe' (Rousseau 1997, 151).

Rousseau argues that natural pity was 'a principle which Hobbes did not notice' (Rousseau 1997, 151). In fact, following Aristotle, Hobbes does include pity as one of the passions of man in Leviathan (1651), arguing that it 'ariseth from the imagination that the like calamity may befall himselfe' (Hobbes 1996, 43). Rousseau's rejection of the imagination in natural man precludes Aristotelian pity, which always begins as an act of rational self-reflection (Aristotle 1984, 1386a). As Rousseau argues, 'it is reason that engenders amour propre, and reflection that reinforces it; reason turns man back upon himself' (Rousseau 1997, 153). Having tied primitive man to the wolf and the monkey, Rousseau uses the heuristic fiction of an animal-like 


\section{Sean Gaston}

non-rational, non-reflective natural pity to launch his first sustained attack on Mandeville. He writes:

I do not believe I need fear any contradiction in granting to man the only Natural virtue [la seule vertu Naturelle] which the most extreme Detractor of human virtue was forced to acknowledge. I speak of Pity, a disposition suited to beings as weak and as subject to so many ills as we are; a virtue all the more universal and useful to man as it precedes the exercise of all reflection in him and so Natural that even the Beasts sometimes show evident signs of it [si Naturelle que les Bêtes memes en donnent quelquesfois des signes sensibles]. To say nothing of the tenderness Mothers feel for their young and of the dangers they brave in order to protect them, one daily sees the repugnance of Horses to trample a living Body underfoot; An animal never goes past a dead animal of its own Species without some restlessness: Some even give them a kind of burial; and the mournful lowing of Cattle entering a Slaughter-House conveys their impression of the horrible sight that strikes them. (Rousseau 1997, 152; Rousseau 1969, 84)

Rousseau challenges Mandeville on his own grounds: surely even Mandeville recognises that there is a natural pity and the author of The Fable of the Bees cannot refute the evidence, or the tropes and fables - the fiction of the animal as moral example-of the pity shown by animals. Animals, Rousseau suggests, not only show pity for their own offspring they also show pity for the dead (or soon to be killed) of their own species (Fontenay 1998, 482). Some, such as the horse, may even show pity for other species, for humans. According to Rousseau, pity is 'Natural virtue' or 'disposition' that can also be taken as the premoral origin and possibility of 'moral relations' in general. As he writes: 'from this single attribute flow all the social virtues' (Rousseau 1997, 153). Natural pity suggests that the social virtues have their origins in animal-like instincts that equate and intertwine animal and human behaviour and preceded abstract categories of good and bad or right and wrong.

Rousseau insists that this animal-like pity is neither historical nor cultural. At the same time, as Derrida suggested, when Rousseau acknowledges that 'some' animals even provide a 'kind of burial' for their own kind he gestures to the possibility of complex and differentiated animal culture (Derrida 2009, 16). Despite his intention to mark out a purely natural virtue through the assertion of a self-evident analogy with the animal, which both relies on empirical examples and non-empirical fabula, Rousseau describes a natural and cultural domain. The fabula of the animal already suggests that natural pity must contest a series of fictions if it is to be the index and origin of moral philosophy. 
Rousseau, Mandeville and the Animal-Fable

\section{The Fables of Virtue: Une Bête Féroce and La Mère}

Most likely having read the 1740 French translation of Mandeville's work, Rousseau is unequivocal in his condemnation of The Fable of the Bees (Mandeville 1988, I: xxxvi-vii). As 'the most extreme Detractor of human virtues' (le Detracteur le plus outré des vertus humaines), even more extreme than Hobbes, he argues that Mandeville is 'forced to acknowledge' (forcé de reconnoître) pity as a 'Natural virtue' (Rousseau 1997, 152; Rousseau 1969, 84). This emphasis on the force of pity as a natural virtue reinforces Rousseau's argument that this seemingly weak ideal has the strength to be the single and pure source of 'all the social virtues', including clemency, humanity, benevolence and friendship (Rousseau 1997, 153). As Derrida noted in Of Grammatology (1967), Rousseau has a remarkable confidence in the force of pity, almost as if it were an Aristotelian dumamis and the social virtues the energeia or actualisation of this natural force. ${ }^{3}$ He writes: 'Mandeville clearly sensed that, for all their morality, men would never have been anything but monsters if Nature had not given them pity in support of reason: but he did not see that from this single attribute flow [de cette seule qualité découlent] all the social virtues he wants to deny men' (Rousseau 1997, 153; Rousseau 1969, 85). At the same time, this force is also always tied to the fablua of the animal that makes its presentation possible. In this sense, Rousseau is following Mandeville.

In his reading of Mandeville, Rousseau cites a passage from 'An Essay on Charity and Charity-Schools' that first appeared in the 1723 edition of The Fables of the Bees, in which Mandeville acknowledges 'all Mankind are more or less affected' by pity (Mandeville 1988, I: 254). To illustrate his own point Mandeville had used the example of witnessing a wild animal - that which is again outside of the law and a fable for what could not be human action - tearing a baby apart. 'What Tortures would it give the Soul beyond Expression!' he exclaims (Mandeville 1988, I: 255). In fact, Mandeville offers two different fables or animal fictions to make his case for the ubiquitous human quality of pity.

The first depicts a scene where we find ourselves 'lock'd up in a Ground-Room' and see a three-year-old child playing very close to us in the yard. If 'a nasty over-grown Sow' then comes into the yard and set the child 'screaming and frighten it out of its Wits', Mandeville notes that this would make us 'uneasy' and lead us to act to drive the sow away. Mandeville is most likely referring here to Locke's argument that the will is prompted to action by a particular and 'present uneasiness' as opposed to a general idea of 'the greater good' (Locke 1979, 253-4). Mandeville moves beyond Locke with his second fiction. 
In the first fable, it is the child's overwrought reaction that generates the spectator's unease. In the second fable or hypothetical narrative, rather than a mere 'nasty over-grown Sow' coming into the yard, Mandeville asks what would happen if 'an half-starv'd Creature, that mad with Hunger went roaming about in quest of food' came into the yard. Mandeville writes:

But if [...] we should behold the ravenous Brute, in spite of our Cries and all the threatening Gestures we could think of, actually lay hold of the Infant, destroy and devour it; To see her widely open her destructive Jaws, and the poor Lamb beat down with greedy haste; to look on the defenceless Posture of tender limbs first trampled on, then tore asunder; to see the filthy Snout digging in the yet living Entrails suck up the smoking Blood, and the cruel Animal with savage Pleasure grunt over the horrid Banquet; to hear and see all this, What Tortures would it give the Soul beyond Expression!

It is hard to imagine how Rousseau could take this exceptionally violent and graphic scene as a proclamation of natural pity. However, Mandeville's description of the dying child as 'the poor Lamb' reinforces the link between Jesus and the Lamb of God and Rousseau not only amplifies the pathos of this scene but also, as we have seen, offers a counter fable of numerous examples of pitying animals to this narrative of 'the cruel Animal'. Starting and ending with the mother-animal and human-animal in the Second Discourse, Rousseau writes:

I speak of Pity, a disposition suited to beings as weak [foibles] and as subject to so many ills as we are; a virtue all the more universal and useful to man as it precedes the exercise of all reflection in him and so Natural that even the Beasts sometimes show evident signs of it. To say nothing of the tenderness Mothers feel [de la tendresse des Méres] for their young and of the dangers they brave in order to protect them, one daily sees the repugnance of Horses to trample a living Body underfoot; An animal never goes past a dead animal of its own Species without some restlessness: Some even give them a kind of burial; and the mournful lowing of Cattle entering a Slaughter-House conveys their impression of the horrible sight that strikes them. It is a pleasure to see the author of the Fable of the Bees forced to recognize [force de reconnoitre] man as a compassionate and sensitive Being, and abandon, in the example he gives of it, his cold and subtle style, to offer us the pathetic picture of a man locked up, who outside sees a ferocious Beast tearing a Child from his Mother's breast [du sein de sa Mére], breaking his weak limbs with his murderous fangs, and tearing the Child's throbbing entrails with its claws. What a dreadful agitation must not this witness to an event in which he has no personal interest whatsoever experience? What anguish must he not suffer at this sight, for not being able to give any help to the fainted Mother [la Mére évanoüie] or the dying Child? (Rousseau 1997, 152; Rousseau 1969, 84-5) 
One might be tempted to ask Rousseau why he has introduced a mother that cannot defend or sacrifice herself to save her child from such a terrible fate. But it is clear that the fable of pity enjoins the natural instincts of both animals and humans through the figure of the mother (Derrida 1976, 145; 265-6; 271). Pity is a natural virtue not so much because of the reaction of the disinterested stranger to the sight of pornographic violence-Rousseau echoes the image of the living, throbbing entrails, les entrailles palpitantes-but because animals also have pitying mothers. Note, that once again, Rousseau associates the weak humans with this powerful force of pity that transcends the vast differences between animals and humans and, most all, forces a denier of human virtue to recognises its power; one might even say its sovereign power.

\section{Animal Passions: The Passion}

One of the problems with Rousseau's account of Mandeville is that he misreads the author of The Fable of the Bees. Mandeville does in fact not use this dramatic scene to argue that pity is a natural virtue. He uses it to mark the difference between the pre-moral or nonmoral passions - which include pity - and the rational virtues that lead to reflective disinterested actions (Mandeville 1988, I: 254). ${ }^{4}$ As he states at the outset of his fable, which we now see is a fable of the passions, pity is 'a Passion of ours [...] which consists in a Fellow-feeling and Condolence for the Misfortunes and Calamities of others: all Mankind are more or less affected with it; but the weakest Minds generally the most' (Ibid. I: 254). One can better understand Rousseau's emphasis on the force and power of pity here, as he attempts to counteract Mandeville's insistence that 'the weakest Minds' are most affected by pity. In this war of fables, it is a question of illustrating the truth of pity as either a virtue or as a passion.

Again, following Locke, Mandeville initially defines pity as a passion that is raised in us 'when the Sufferings and Misery of other Creatures make so forcible an Impression upon us, as to make us uneasy' (Ibid. I: 254). At the same time, Mandeville's second fable goes well beyond unease. Rousseau is quite right to see a change in style and tone when Mandeville exclaims: 'What Tortures would it give the Soul beyond Expression!'. However, this heightened tone describes the animal-like passions of humans not their capacity for virtuous actions. Mandeville attempts to keep a clear barrier between the animal passions and human virtues. Pity is an animal passion like anger, fear or courage. It is not 
a virtue or what Mandeville calls 'a rational ambition of being Good' (Ibid. I: 260). Passions cannot be disinterested, he argues, because 'all passions centre in Self-Love' - even pity (Ibid. I: 75). ${ }^{5}$ In this sense, Mandeville, the apparent bête noire of eighteenth-century philosophy, is far more conventional in using animal-fables to mark limits than Rousseau who uses them to indicate possibilities.

At the same time, despite its evident limitations, Mandeville celebrates the purity of this animal-like passion of pity, precisely because it is not the fable or fiction of an ideal virtue. He writes:

Let me see the most shining Virtue the Moralists have to boast of so manifest either to the Person possess'd of it, or those who behold his Actions: Let me see Courage, or the Love of one's Country so apparent without any Mixture, clear'd and distinct, the first from Pride and Anger, the other from the Love of Glory, and every Shadow of Self-Interest, as this Pity would be clear'd and distinct from all other Passions. (Ibid. I: 256)

This pity in extremis is an exceptional passion for Mandeville, who advocates an unavoidable mixture of passions as well as of virtues and vices for those who live in civil and commercial societies. However, the clarity of this seemingly unmixed passion is grounded on its animal-like resonance with a far more profound source of ideal virtue: we stand by helplessly as 'the poor Lamb' is devoured by a ravenous beast. This is an animal-fable of the Passion.

In contrast to Rousseau's use of the fable to equate the animal and human as a common source of a pre-social virtue, Mandeville's critique of civil society is founded on the oldest of fables: The Passion. From the Passion, human passions are always limited. As he writes elsewhere in The Fable of the Bees, 'no Body is so Savage that no Compassion can touch him, nor any Man so good-natur'd as never to be affected with any Malicious Pleasure' (Mandeville 1988, I: 140). It is in this context that one should read his litany of the limitations of the social passion of pity, which may be prompted by envy or self-preservation (Ibid., I: $139-40$; I: 82-3).

Mandeville also treats this fallen pity as a social strategy and, more significantly, challenges its ability to be a powerful natural virtue. Pity may be a natural instinctive passion but it lacks the force to be a virtue. He writes:

It is impossible to judge of a Man's performance, unless we are thoroughly acquainted with the Principle and Motive from which he acts. Pity, tho' it is the most gentle and the least mischievous of all of our Passions, is yet 
as much a Frailty of our Nature, as Anger, Pride, or Fear. The weakest Minds have generally the greatest share of it, for which Reason none are more Compassionate than Women and Children. It must be own'd, that of all our Weaknesses it is the most amiable, and bears the greatest Resemblance to Virtue; nay, without a considerable mixture of it the Society could hardly subsist: But as it is an impulse of Nature, that consults neither the publick Interest nor our own Reason, it may produce Evil as well as Good. It has help'd to destroy the Honour of Virgins, and corrupted the Integrity of Judges; and whosever acts from it as a Principle, what good soever he may bring to the Society, has nothing to boast of but that he has indulged a Passion that has happened to be beneficial to the Publick. (Ibid. I: 56)

Mandeville makes an important distinction here: pity 'bears the greatest Resemblance to Virtue' but as an 'impulse of Nature' it is not itself a virtue. Pity plays a critical role in civil society but it does not necessarily require a 'Principle and Motive' for acting in 'the publick Interest' based on the use of 'our own Reason'. Mandeville is not that far from Kant here (Kant 1996, 535-6).

While it has been pointed out that Mandeville primarily sees the individual in commercial and civic society as subsumed by a sea of passions, it can be argued that he nonetheless grounds the elusive and rare acts of virtue in such a society on rational action. ${ }^{6}$ As Cleomenes remarks in second part The Fable of the Bees, 'Action' in 'a free Agent' is 'the inward Motive of the Mind, that put him upon performing it' (Ibid. II: 120, 118). ${ }^{7}$ Reason has its evident limitations, but the virtuous motive can be discerned in the difficult action of rational self-denial, of temporarily checking one's passions, in the midst of the pressures and inducements of a prosperous and seemingly polite commercial society (Ibid. II: 12). ${ }^{8}$ These acts are rare-but they are possible (Ibid. I: 57). Reason marks the possibility of rising above the limitations of both the passions and the legacy of the Passion.

In contrast, the primal scenes of pity are an example of pure passion, Mandeville argues, because 'there would be no need of Virtue or SelfDenial to be moved at such a Scene'. Virtue requires self-denial and the action of self-denial distinguishes good men from bad men (Ibid. I: 256). Animal-like, the fable of the pure passion of pity is unable to register such moral distinctions. Mandeville observes: 'not only a Man of Humanity, of good Morals and Commiseration, but likewise an Highwayman, an House-Breaker, or a Murderer could feel Anxieties on such an Occasion' (Ibid. I: 256). As a passion, Mandeville insists, pity can be felt by both the virtuous and unvirtuous alike: it remains the province of the fallen. 


\section{The Limits of Vegetarian Pity}

In the first edition of The Fable of the Bees (1714), Mandeville appears to be quite close to Rousseau when he touches on the question of 'Primitive Pity' in the midst of a discussion of the custom of eating animals. Once again, the question of the animal-fable and human fictions that it both generates and displaces appear at the heart of the discussion of pity. Mandeville writes:

I have often thought, if it was not for this Tyranny which Custom usurps over us, that Men of any tolerable Good-nature could ever be reconcil'd to the killing of so many animals for their daily Food, as long as the bountiful Earth so plentifully provides them with Varieties of vegetable Dainties. (Ibid. I: 173)

Mandeville goes on to note that we pity animals that are killed to be eaten: 'nothing stirs us to Pity so effectually, as when the Symptoms of Misery strike immediately upon our Senses, and I have seen People mov'd at the Noise a live Lobster makes upon the Spit'. Responding to the debate that had started with Rorarius and Descartes, and later involved both Bayle and Leibniz, over whether animals could reason or feel, like Rousseau in the Second Discourse Mandeville describes 'the bitter Sighs' of 'a large and gentle Bullock' that 'speak the Sharpness of his Anguish, and the deep sounding Grones with loud Anxiety fetch'd from the bottom of his strong and palpitating Heart' as he is killed (Ibid. I: $180-81$; II: 166). ${ }^{9}$

At the same time, as Derrida remarks in The Animal That Therefore I Am (1997), in the tradition of the fable and of the 'fabulous animal' as a 'speaking animal' that 'speaks of itself to say "I"', Mandeville reinforces his theory of the natural passion of pity through a fable in which a lion explains why he will kill and eat a merchant that he has found while hunting (Derrida 2008, 66). To justify his actions the lion remarks: 'Savage I am, but no Creature can be call'd cruel but what either by Malice or Insensibility extinguishes his Natural Pity: The Lion was born without Compassion; we follow the Instinct of our Nature' (Mandeville 1988, I: 178). Mandeville suggests the feint of a counter genealogy here: the human passions and its failings are marked by the primal scene of the Passion, but animal passions - which illustrate what cannot be illustrated as the proper of man-indicate the origin as a passion without compassion, a passion that produces no heuristic fiction of moralism. It is from this perspective that one can read Mandeville's quasi-anthropological assertion that our reluctance to be involved in 
the slaughter of animals whilst enjoying the prepared meat on our plates is the 'strong remains of Primitive Pity and Innocence, which all the arbitrary Power of Custom, and the violence of Luxury, have not yet been able to conquer' (Mandeville 1988, I: 174; Fontenay 1998, 483-87).

\section{Without the Animal: Reason}

Rousseau's equation of pity with an animal-like state that is pre-rational, pre-social and pre-moral provoked many of his contemporary readers, notably Samuel Johnson and Adam Smith. ${ }^{10}$ Prompted by his orthodox religious convictions and conservative political views, Johnson was unequivocal in his condemnation of Rousseau. 'I think him one of the worst of men; a rascal who ought to be hunted out of society', he told Boswell (Boswell 1998, 359). ${ }^{11}$ Johnson dismissed the Second Discourse on the grounds of its apparent advocacy of a savage state of autonomy or equal independence that has no use in negotiating the very real and necessary inequalities of civil society (Boswell 1998, 311). ${ }^{12}$ As Johnson remarks, Rousseau's analysis of the origins of inequality leads to calls for an equality that reduces humans to an animal-like level: 'Were we all upon an equality, we should have no other enjoyment than mere animal pleasure' (Boswell 1998, 313). ${ }^{13}$

In his London Journal, Boswell transcribed his original conversation with Johnson in 1763, recording: 'Johnson said that pity was not a natural passion' (Boswell 1950, 312). Johnson suggests, contrary to both Mandeville and Rousseau, that pity is neither a natural passion nor an instinctive virtue. Without recourse to animal-like levels of moral development Johnson appears to remove pity from both nature and from the fabula of animals. Pity is a moral, rational and social virtue: it is an exclusively human virtue. Boswell writes:

On Wednesday, 20 July, Dr. Johnson, Mr. Dempster, and my uncle Dr. Boswell, who happened to be now in London, supped with me at these Chambers. JOHNSON. 'Pity is not natural to man. Children are always cruel. Savages are always cruel. Pity is acquired and improved by the cultivation of reason. We may have uneasy sensations from seeing a creature in distress, without pity; for we have not pity unless we wish to relieve them. When I am on my way to dine with a friend, and finding it late, have bid the coachmen make haste, if I happen to attend when he whips his horses, I may feel unpleasantly that the animals are put in pain, but I do not wish him to desist. No, Sir, I wish him to drive on'. (Boswell 1998, 309) 
Nonetheless, if pity is 'not natural to man', if it is entirely 'acquired and improved by the cultivation of reason', Johnson still relies on an example of the relation between humans and animals. Rousseau may have implied that horses instinctively feel pity for humans, but Johnson makes it clear that a human pity, founded on social and civil reasoning, in turn offers no pity for the animal. Or rather, Johnson suggests that a socially conditioned human may 'feel unpleasantly that the animals are put in pain' but has reasons, rational and self-interested goals and ends, which override this animal directed pity. ${ }^{14}$ Reason is the source of pity and the origin of its absence both in the animal and for the animal. Reason is the fable of thinking without the animal.

\section{Reading Rousseau with Mandeville}

'It is by the help of this style, together with a little philosophical chemistry, that the principles and ideas of the profligate Mandeville seem in him to have all the purity and sublimity of the morals of Plato' (Smith 1982, 250). Adam Smith offered this equivocal praise for Rousseau's Second Discourse in a short-lived Edinburgh periodical in 1755. Smith goes out of his way to associate Rousseau's work with one its own principal targets of criticism. He writes: 'the Fable of the Bees has given occasion to the system of Mr. Rousseau, in whom however the principles of the English author are softened, improved, and embellished, and stript of all that tendency to corruption and licentiousness which has disgraced them in their original author' (Smith 1982, Ibid. 250). According to Smith, Rousseau offers a decorous and less heterodox version of The Fable of the Bees. From this point of view, one would have to take Rousseau's argument for a natural animal-like virtue as a consequence of Mandeville's restriction of pity to the morally unreliable animal-like passions. The fabula of pity as a limited and fallen passion gives rise to the fabula of pity as a natural virtue and the possibility of morality in civil society. Within a moral philosophy that is structured by fables of pity, limit would then be the origin of possibility and passion the origin of virtue. The possibilities of virtue would be the reaction against the limitations of passion: a natural history of moral philosophy.

At the same time, despite this quite remarkable double reading of Rousseau with Mandeville, Smith acknowledges in his review that Rousseau sees his own work in a very different light. 'Mr. Rousseau', Smith remarks, 'however criticises upon Dr. Mandeville: he observes, that pity, the only amiable principle which the English author allows to be natural to man, is capable of producing all those virtues, whose 
reality Dr. Mandeville denies' (Smith 1982, 251). Following Smith, it is the fables of pity that ensure the ideality of an untouchable difference between the possibilities of virtue and the limitations of passion. This is the heuristic value of the animal-fable and its fictions.

Smith provides his own critical analysis of Rousseau's case for pity as a natural virtue. 'Mr. Rousseau at the same time seems to think', Smith observes, 'that this principle is in itself no virtue, but that it is possessed by savages and by the most profligate of the vulgar, in a greater degree of perfection than by those of the most polished and cultivated manners; in which he perfectly agrees with the English author' (Smith 1982, 251). Despite his protestations, Rousseau is once again closer to Mandeville than he would care to admit. At the same time, when Smith states that Rousseau 'seems to think, that this principle is in itself no virtue', he either misreads Rousseau - it is very clear that pity is a natural virtue-or he is using a particularly sinuous rhetoric to register his own view that a primitive and pre-moral and pre-social instinct cannot be called a virtue.

In his dismissal of the natural virtue of pity Smith says nothing about Rousseau's use of examples or fabula of animals expressing pity or of the implicit blurring of the boundaries between the human and the animal. He restricts himself to linking it to savages-Rousseau's primitive man-and to 'the most profligate of the vulgar', which is a reference to Mandeville's view that pity is a common passion that has no fixed association with the moral categories of either virtue or vice. Like Johnson, who confined his analysis of pity to human action, Smith implies that Rousseau's fine theory of natural pity cannot avoid moral relativism. In this sense, Smith must exclude the animal-fable from his attempt to blur the boundaries between Rousseau and Mandeville.

Nonetheless, it is notable that in the opening of The Theory of Moral Sentiments (1759-90), Smith begins by announcing not the possibilities but the limitations of pity as the best grounds for a theory of moral sentiments (Leigh 1986, 12). 'Pity and compassion', he writes, 'are words appropriated to signify our fellow-feeling with the sorrow of others. Sympathy, though its meaning was, perhaps, originally the same, may now, however, without much impropriety, be made use of to denote our fellow-feeling with any passion whatever' (Smith 2002, 13). The generality of a concept of sympathy, guided by judgements of propriety, merit and duty, provides a more effective basis for a theory of moral sentiments (Force 2003, 19-23). It is a question here of a moral philosophy in general: of an empirically-based moral philosophy at its most general. The generality of this philosophy must move beyond the limitations of pity and the fables of pity. 


\section{Sean Gaston}

For Smith, the animal-fable as a structure for thinking pity (as either a virtue or a passion) can only return us to the moral impasses of Mandeville and Rousseau. The pity and the sorrow we feel 'from the sorrow of others', Smith argues, 'like all the other original passions of human nature, is by no means confined to the virtuous and humane, though they perhaps may feel it with the most exquisite sensibility. The greatest ruffian, the most hardened violator of the laws of society, is not altogether without it' (Smith 2002, 11). At the same time, Smith cannot entirely exclude the animal-fable and its fictions from his generalised moral philosophy when, as Derrida argued in La Bête et le souverain, it comes to demarcating the uniquely human problem of violence and cruelty, of acting like a beast in civil society.

Smith devotes a few pages to animals in the midst of his discussions of the sentiments of reward and punishment. He associates an animallike behaviour in humans with 'an absurd sort of vengeance', a passion that is so strong that it momentarily creates the delusion or fiction that inanimate objects can be punished. Smith writes:

The cause of pain and pleasure, whatever they are, or however they operate, seem to be the objects, which, in all animals, immediately excite those two passions of gratitude and resentment. They are excited by inanimated, as well as animated objects. We are angry, for a moment, even at the stone that hurts us. A child beats it, a dog barks at it, a choleric man is apt to curse it. The least reflection, indeed, corrects this sentiment, and we soon become sensible, that what has no feeling is a very improper object of revenge. (Smith 2002, 110)

It is apparently only at a common or comparative level between animals and humans that one can describe such human errors.

For Smith, 'before anything can be the proper object of gratitude or resentment, it must not only be the cause of pleasure and pain, it must likewise be capable of feeling them' (Smith 2002, 111). In other words, there will be less fictionality when humans can express feelings toward an animate object, such as an animal, which can share basic feelings of pain and pleasure. 'Animals, therefore', Smith writes, 'are less improper objects of gratitude and resentment than inanimated objects' (Ibid. 111). The animals without fables that serve or injure humans can then be rewarded or punished accordingly. One cannot reward or punish an animal-fable and it appears that Smith has managed to remove the fabulous from the animal in his generalised philosophy. A theory of moral sentiments must keep a clear division between the particular limitations of animals and the general possibilities of humans. As Smith 
concludes, 'though animals are not only the causes of pleasure and pain, but are also capable of feeling those sensations, they are still far from being complete and perfect objects, either of gratitude or resentment; and those passions still feel, that here is something wanting in their entire gratification' (Ibid. 112).

At the same time, Smith cannot extricate himself from the tradition of the animal-fable as a means of articulating a moral philosophy for a civil society. Because, he writes, 'men, though naturally sympathetic, feel so little for another, with whom they have no particular connexion', the natural awareness of the power of the social conventions of justice alone stop men acting 'like wild beasts' and prevent a man entering 'an assembly of men as he enters a den of lions' (Ibid. 101-2). As Derrida suggested, when it a question of men acting like wild beasts, eighteenthcentury moral philosophy is encountering the great shibboleth of the period: the use the animal as a political fable for a sovereign extremis that stands outside or above the law. The animal-fable allows moral philosophy to imagine the animal-like fiction of humans that place themselves beyond ideas of justice, natural conscience and the 'terrors of merited punishment which attend upon its violation' (Ibid. 101).

Towards the end of his account of the sentiments of reward and punishment, Smith warns against disregarding even the inadvertent 'evil' that we do to others. We should, he warns, all 'dread that animal resentment' that can come, suddenly, from other humans who feel injured or aggrieved (Ibid. 125). Unlike Rousseau, Smith cannot allow for the fiction of an animal-like pity that has the same force and assurance as the 'animal resentment' that polices and threatens all civil societies. This is where a moral philosophy that remains silent about the political constitution of the state encounters again and again what Derrida called the 'artificial monstrosity of the animal', or 'the figure without figure of a mythological, fabulous, and non-natural monstrosity' that registers 'the essence of the political and, in particular of the state and sovereignty' (Derrida 2009, 49).

\section{References}

Alkon, Paul Kent (1967), Samuel Johnson and Moral Discipline, Evanston: Northwestern University Press.

Aristotle (2000), Nicomachean Ethics, Roger Crisp (ed.), Cambridge: Cambridge University Press.

(1984), Rhetoric, in The Complete Works of Aristotle, Jonathan Barnes (ed.), 2 vols., Princeton: Princeton University Press. 
Bayle, Pierre (1991), 'Rorarius', in Bayle: Historical and Critical DictionarySelections, trans. and ed. Richard H. Popkin and Craig Brush, Indianapolis: Hackett, pp. 213-54.

Berger, Anne-Emmanuelle and Marta Segara (2011), Demenagaries: Thinking (of) Animals After Derrida, Amsterdam: Rodopi.

Boswell, James (1928), 'The Hypochrondriack', in Margery Bailey (ed.), London Magazine Nov. 1777- Aug. 1783), 2 vols., Stanford: Stanford University Press.

Boswell, James (1998), Life of Johnson, R. W. Chapman (ed.), Oxford: University of Oxford Press.

Boswell, James (1950), London Journal 1762-1763, Frederick A. Pottle (ed.), London: Heinemann.

Boyd, Richard (2004), 'Pity's Pathologies Portrayed: Rousseau and the Limits of Democratic Compassion', Political Theorv, 32:4, pp. 519-46.

Calarco, Matthew (2008), Zoographies: The Question of the Animal from Heidegger to Derrida, New York: Columbia University Press.

Chapin, Chester F. (1968), The Religious Thought of Samuel Johnson, Ann Arbour: University of Michigan Press.

Cooper, Anthony Ashley, Third Earl of Shaftesbury (1999), 'An Inquiry Concerning Virtue or Merit', in Lawrence E. Klein (ed.), Characteristics of Men, Manners, Opinions, Times, Cambridge: Cambridge University Press, pp. 163-230.

Coski, R. Christopher (2003), 'Condillac: Language, Thought and Morality in the Man and Animal Debate', French Forum, 28:1, pp. 57-75.

Derrida, Jacques (2008), The Animal That Therefore I Am, Marie-Louise Mallet (ed.), David Wills (trans.), Stanford: Stanford University Press.

Derrida, Jacques (1976), Of Grammatology, Gayatri Chakravorty Spivak (trans.), Baltimore: Johns Hopkins University Press.

Derrida, Jacques (2007), 'Psyche: Invention of the Other', in Psyche: Inventions of the Other, Volume 1, Peggy Kamuf and Elizabeth Rottenberg (ed.), Catherine Porter (trans.), Stanford: Stanford University Press, pp. 1-47.

Derrida, Jacques (2009), The Beast and the Sovereign: Volume 1, Michel Lisse, Marie-Louise Mallet and Ginette Michaud (eds.), Geoffrey Bennington (trans.), Chicago: University of Chicago Press.

Descartes, René (1986), Meditations on First Philosophy, in Philosophical Writings, John Cottingham, Robert Stoothoff and Dugald Murdoch (trans.), 2 vols., Cambridge: Cambridge University Press.

Duff, Edward (1979), Rousseau in England: The Context for Shelley's Critique of the Enlightenment, Berkeley: University of California Press.

de Fontenay, Élisabeth (1998), Le Silence des bêtes: la philosophie à l'épreuve de l'animalité, Paris: Fayard.

Force, Pierre (2003), Self-Interest before Adam Smith: A Genealogy of Economic Science, Cambridge: Cambridge University Press.

Garrett, Aaron (2000), Animal Rights and Souls in the Eighteenth Century, 6 vols., Bristol: Thoemmes Press.

Gaston, Sean (2010), 'The Impossibility of Sympathy', The Eighteenth Century: Theory and Interpretation, 51: 1-2, pp. 129-52.

Gaston, Sean (2011), 'Pity, Virtuality and Power', in Sean Gaston and Ian Maclachlan (eds.), Reading Derrida's Of Grammatology, London: Continuum, pp. 129-31.

Goldsmith, M. M. (2000), 'Mandeville's Pernicious System', in Charles W. A. Prior (eds.), Mandeville and Augustan Ideas: New Essays, Victoria: English Literary Studies. 
Hobbes, Thomas (1996), Leviathan; or, The Matter, Forme, \& Power of a Common Wealth Ecclesiastical and Civill, Richard Tuck (ed.), Cambridge: Cambridge University Press, 1996.

Hume, David (2001), A Treatise of Human Nature, David Fate Norton and Mary J. Norton (eds.), Oxford: Oxford University Press.

Jack, Malcolm (1989), Corruption \& Progress: The Eighteenth Century Debate, New York: AMS Press.

Johnson, Samuel (1963), The Idler and The Adventurer, W. J. Bate, John M. Bullitt and L. F. Powell (eds.), New Haven: Yale University Press.

Kant, Immanuel (1996), The Metaphysics of Morals, in Practical Philosophy, Mary Gregor (trans.), Cambridge: Cambridge University Press.

Leibniz, G. W. (1998), Philosophical Texts, R. S. Woolhouse (ed.), Richard Francks and R. S. Woolhouse (trans.), Oxford: Oxford University Press.

Leigh, R. A. (1986), 'Rousseau and the Scottish Enlightenment', Contributions to Political Economy 5, pp. 1-22.

Locke, John (1979), An Essay Concerning Human Understanding, Peter H. Nidditch (ed.), Oxford: Clarendon Press.

Mandeville, Bernard (1988), The Fable of the Bees: Or Private Vices, Publick Benefits, F. B. Kaye (ed.), 2 vols., Indianapolis: Liberty Fund.

Marshall, David (1988), The Surprising Effect of Sympathy: Marivaux, Diderot, Rousseau, and Mary Shelley, Chicago: University of Chicago Press.

Menely, Tobias (2007), 'Zoöphilpsychosis: Why Animals are What's Wrong with Sentimentality', Symploke 15:1-2, pp. 244-67.

Morgensten, Mira (1996), Rousseau and the Politics of Ambiguity: Self, Culture and Society, Pennsylvania State University Press.

Palmeri, Frank (2006), 'Autocritique of Fables', in Frank Palmeri (ed.), Humans and Other Animals in Eighteenth-Century Culture: Representation, Hybridity, Ethics, New York: Ashgate, pp. 83-100.

Rorarius, Hieronymous (Jerome) (2005), Quod animalia bruta ratione utantur melius homine, Jean Ecloe (ed.), Hildesheim: Georg Olms.

Rousseau, Jean-Jacques (1997), Discourse on the Origin and Foundations of Inequality Among Men, in The Discourses and other Early Political Writings, Victor Gourevitch (ed. and trans.), Cambridge: Cambridge University Press, pp. 111-222.

Rousseau, Jean-Jacques (1969), Discours sur l'origine et les fondements de l'inégalité parmi les hommes, Jean Starobinski (ed.), Paris: Gallimard.

Sewall, Richard B. (1949), 'Dr. Johnson, Rousseau, and Reform', in Frederick Whiley Hilles (ed.), The Age of Johnson: Essays Presented to Chauncey Brewster Tinker, New Haven: Yale University Press, pp. 307-18.

Smith, Adam (1982), 'A Letter to the Authors of the Edinburgh Review', in W. P. D. Wightman and J. C. Bryce (eds.), Essays on Philosophical Subjects, Indianapolis: Liberty Fund, pp. 242-54.

Smith, Adam (2002), The Theory of Moral Sentiments, Knud Haakonssen (ed.), Cambridge: Cambridge University Press.

Starobinski, Jean (1995), 'Note sur l'éstablissement du text', in Bernard Gagnebin and Marcel Raymond (eds.), Jean-Jacques Rousseau, Oeuvres Complètes V, Paris: Gallimard, cxcvii-cciv.

Steiner, Gary (2005), Anthropocentrism and its Discontents: The Moral Status of Animals in the History of Western Philosophy, Pittsburgh: Pittsburgh University Press, pp. 177-80

Steintrager, James A. (2004), Cruel Delight: Enlightenment Culture and the Inhuman, Bloomington: Indiana University Press. 
Trachtenberg, Zev (2009), 'Civic Fanaticism and the Dynamics of Pity', in Ourdia Mostefai and John T. Scott (eds.), Rousseau and l'infâme: Religion, Toleration, and Fanaticism in the Age of Enlightenment, Amsterdam: Rodopi, pp. 203-26.

Voitle, Robert (1961), Samuel Johnson the Moralist, Cambridge: Harvard University Press.

Wolloch, Nathaniel (2008), 'Rousseau and the Love of Animals', Philosophy and Literature 32:2, pp. 293-302.

\section{Notes}

1. See Matthew Calarco (2008); Anne-Emmanuelle Berger and Marta Segara (2011). See also Frank Palmeri (2006); Gary Steiner (2005), 177-80; Nathaniel Wolloch (2008); Coski R. Christopher (2003); Aaron Garrett (2000).

2. See also Derrida (2007).

3. See Derrida (1976), pp. 171-92. See also Gaston (2011).

4. See also Hume (2001), p. 238.

5. See also Mandeville (1988), pp. I: 142, 156.

6. On the authority of the passions in Mandeville see: Steintrager (2004) pp. 45-9; Goldsmith (2000) pp. 80-1; Jack (1989) pp. 40-1.

7. See also Aristotle (2000), 1106a.

8. Mandeville is also challenging Shaftesbury here and what he sees as an all too easy equation of 'Virtue with good Manners' and a belief 'that Men may be Virtuous without Self-denial' (Mandeville 1988, I: 333; II: 20). See also I: 369, II: 7, 11, 41. See Anthony Ashley Cooper (1999).

9. See Rorarius (2005); Descartes (1986) II: 58, 96, 248; Bayle (1991), 213-54; Leibniz (1998), 120, 198-200, 218, 260-1.

10. See, Morgensten (1996), pp. 55, 59-60; Boyd (2004), pp. 522-3, 528-9; Tobias Menely (2007), pp. 244-67; Trachtenberg (2009), pp. 203-26; Starobinski (1995), pp. ci-ciii, 1559-61; Marshall (1988), pp. 147-51.

11. See also Sewall (1949); Chapin (1968), pp. 92-105. Johnson's essay in The Idler from 1758 (No. 4 Saturday, 6 May 1758) on charity has also been seen as a direct refutation of Mandeville. For Johnson, it is Mandeville's failure to recognise the Passion as origin that limits his view of social morality. The Fable of The Bees lacks the fundamental recognition of piety and 'the light of revelation' that must prompt all acts of pity, Johnson (1963), p. 13. See also Alkon (1967), pp. 39-45; Voitle (1961), pp. 51-6.

12. See also Duff (1979), p. 437.

13. For Johnson's other observations on animals, see $525,652,657,753,911-12$, 1216-17, 1357.

14. The influence of Johnson's sceptical view of natural pity on Boswell can be seen in The Hypochrondriack papers that Boswell contributed to the London Magazine from 1777 to 1783 . Boswell argues in an essay from 1780 that to be 'the object of pity is a situation very humiliating' and sign of 'inferiority' (Boswell 1928, I: 325). He also questions the motives of those who express pity, insisting that the happy are 'little disposed to pity others who are distressed' and that there are often motives of contempt and self-interest in those who pity, not least in wishing 'to get rid of uneasiness' that the distress of others makes them feel (I: 326-7). He concludes that pity is something that is taught and socially determined and is as much an artificial quality-a fiction-as the 'artificial dignity' of those who claim the 'dignity of distress' (I: 327-8). See also I: 326. 